\title{
Description of Wautersiella falsenii gen. nov., sp. nov., to accommodate clinical isolates phenotypically resembling members of the genera Chryseobacterium and Empedobacter
}

Correspondence Mario Vaneechoutte Mario.Vaneechoutte@UGent.be

\author{
Peter Kämpfer, ${ }^{1}$ Véronique Avesani, ${ }^{2}$ Michèle Janssens, ${ }^{2}$ \\ Jacqueline Charlier, ${ }^{2}$ Thierry De Baere ${ }^{3}$ and Mario Vaneechoutte ${ }^{3}$ \\ ${ }^{1}$ Institut für Angewandte Mikrobiologie, Justus-Liebig-Universität Giessen, Germany \\ ${ }^{2}$ Microbiology Unit, Faculty of Medicine, University of Louvain, Brussels, Belgium \\ ${ }^{3}$ Department of Clinical Chemistry, Microbiology and Immunology, University of Ghent, Ghent, \\ Belgium
}

\begin{abstract}
A total of 26 isolates of non-fermenting, Gram-negative rods, obtained between 1980 and 2004 by various clinical laboratories in Belgium, with phenotypic characteristics resembling those of members of the genera Chryseobacterium and Empedobacter (indole-positive) and a biochemical profile resembling that of CDC group II-h, but urease-positive, were collected at the Université Catholique de Louvain Microbiology Laboratory, Belgium. The 16S rRNA gene sequences were determined for most of the isolates and showed 94-95\% similarity with the type strain of Empedobacter brevis as the closest relative, indicating that these isolates might belong to a separate genus. Furthermore, the 16S rRNA gene sequences of the isolates were similar, but two clusters (genomovars) could be distinguished. The sequence similarities were $99 \cdot 5-100 \%$ for the 14 isolates of genomovar 1 and $99 \cdot 4-100 \%$ for the 12 isolates of genomovar 2 . The similarity between the two clusters was $98 \cdot 3-99 \cdot 5 \%$. The presence of two clearly different groups was corroborated by using tRNA intergenic length polymorphism analysis, which also enabled differentiation of the novel species from all other species studied thus far using this technique. DNA-DNA hybridization results excluded a close relatedness to Empedobacter brevis. The DNA $\mathrm{G}+\mathrm{C}$ contents of the reference strains of genomovars 1 and 2 were $33 \cdot 8 \pm 0 \cdot 4$ and $34 \cdot 4 \pm 0.2 \mathrm{~mol} \%$, respectively. The name Wautersiella falsenii gen. nov., sp. nov., is proposed for this group, comprising two closely related genomovars. The type strain of the species and reference strain for genomovar 1 is NF $993^{\top}\left(=\right.$ CCUG $51536^{\top}=$ CIP $\left.108861^{\top}\right)$, which was isolated from a surgical wound. The reference strain for genomovar 2 is NF 770 (= CCUG $51537=$ CIP 108860), which was isolated from blood.
\end{abstract}

The family Flavobacteriaceae, emended by Bernardet et al. (2002), comprises several genera of which Bergeyella, Chryseobacterium and Riemerella form a separate branch

\footnotetext{
Abbreviation: tDNA-PCR, tRNA intergenic length polymorphism analysis.

The GenBank/EMBL/DDBJ accession numbers for the 16S rRNA gene sequences of Wautersiella falsenii genomovar 1 strains NF $993^{\top}$, NF 1182, NF 880, NF 777, NF 869, NF 289, NF 1240, NF 1241, NF 835, NF 1242, NF 1243 and NF 1244 are AM084341 and AM238680-AM238690, respectively, those of Wautersiella falsenii genomovar 2 strains NF 770 (reference strain), NF 622, NF 1159, NF 1249, NF 1140, NF 1084, NF 1080, NF 1136, NF 203, NF 316 and NF 58 are AM084342 and AM238670-AM238679, respectively, and those of Empedobacter brevis strain LMG $4011^{\top}$ and group CDC II-h strain NF 802 are AM177497 and AM261868, respectively.
}

on the basis of rRNA cistron similarity (Vandamme et al., 1994; Bernardet et al., 2002) and whereby the genus Empedobacter (Vandamme et al., 1994) represents a separate line of descent comprising only one species, Empedobacter brevis. We propose a new genus within the Flavobacteriaceae, designated Wautersiella gen. nov., comprising the species Wautersiella falsenii sp. nov., with genomovars 1 and 2 to accommodate two groups of closely related isolates from clinical origins and with phenotypic resemblance to isolates of the genera Chryseobacterium, Weeksella and Empedobacter and of CDC groups II-e and II-h (Schreckenberger et al., 2003).

The 26 isolates, which were obtained between 1980 and 2004 by at least ten clinical laboratories in Belgium, originated from various human clinical samples, including blood, 
wounds, pus, respiratory tract, ear discharge, vaginal swab and pleural fluid (Table 1) and were cultivated on tryptic soy agar containing $5 \%$ sheep blood. Strains of Empedobacter brevis, Weeksella virosa and CDC group II-h used in this study were isolated from different patients in various Belgian hospitals.

16S rRNA gene sequences were determined for most of the isolates as described previously (Wauters et al., 2001) and tree construction was done as described by Nemec et al. (2001).

The results of sequence determination and cluster analysis of the $16 \mathrm{~S}$ rRNA genes are presented in Fig. 1. The Wautersiella falsenii isolates clearly affiliated separately and the 16S rRNA gene sequences showed 94-95\% similarity with the type strain of Empedobacter brevis as the closest relative, indicating that the isolates might belong to a separate genus. Furthermore, the 16S rRNA gene sequences of the isolates were similar, but two clusters (genomovars) could be distinguished. The sequence similarities were 99.5-100 \% for the 14 isolates of genomovar 1 and $99 \cdot 4-100 \%$ for the 12 isolates of genomovar 2. The similarity between the two clusters was $98 \cdot 3-99 \cdot 5 \%$.

It should be noted that the $16 \mathrm{~S}$ rRNA gene sequence of an isolate designated Flavobacterium sp. (GenBank accession no. AY363052), submitted to GenBank in August 2003 by the Institut für Klinische Microbiologie of the University of Erlangen, Germany, showed $100 \%$ similarity with some of the 16S rRNA gene sequences determined for the Wautersiella falsenii genomovar 2 isolates.

tRNA intergenic length polymorphism analysis (tDNAPCR) was carried out as described previously (Baele et al., 2000). Fig. 2 presents the tDNA-PCR fingerprints as obtained for representative strains of Wautersiella falsenii genomovars 1 and 2, Empedobacter brevis, Weeksella virosa and CDC group II-h. The tDNA-PCR fingerprints of isolates from the two genomovars had the following fragments in common: $57 \cdot 6 \mathrm{bp}$ (SD for 11 isolates, $0 \cdot 3 \mathrm{bp}$ ), $90 \cdot 7(0 \cdot 1)$, $101 \cdot 3(0 \cdot 1)$ and $221 \cdot 4 \mathrm{bp}(0 \cdot 2 \mathrm{bp})$, but all genomovar 2 isolates had an additional tRNA spacer of $132 \cdot 9 \mathrm{bp}(0 \cdot 1 \mathrm{bp}$ for 5 isolates).

The three Empedobacter brevis strains (LMG $4011^{\mathrm{T}}$, NF 285 and NF 1052) had tRNA spacers with lengths of $102 \cdot 4(0 \cdot 1)$, $103 \cdot 5(0 \cdot 1), 112 \cdot 0(0 \cdot 1), 113 \cdot 1(0 \cdot 1)$ and $114 \cdot 1 \mathrm{bp}(0 \cdot 1 \mathrm{bp})$ in common. All except strain NF 285 also had spacers with lengths of $99 \cdot 2(0 \cdot 2)$ and $242 \cdot 7 \mathrm{bp}(0 \cdot 1 \mathrm{bp})$ in common and all except strain NF 1052 had spacers of $111 \cdot 0(0 \cdot 1)$ and $241 \cdot 0$ bp $(0 \cdot 7 \mathrm{bp})$ in common.

The three Weeksella virosa strains tested (NF 135, NF 309 and NF 323) had tRNA spacers with lengths of $57 \cdot 6(0 \cdot 5)$, $88 \cdot 0(0 \cdot 1), 98 \cdot 4(0 \cdot 5), 99 \cdot 3(0 \cdot 5)$ and $104 \cdot 0 \mathrm{bp}(0 \cdot 1 \mathrm{bp})$ in common, with strains NF 135 and NF 309 having a spacer of $91.3 \mathrm{bp}(0 \cdot 1 \mathrm{bp})$ in common and NF 135 and NF 323 having spacers of $230 \cdot 4(0 \cdot 1)$ and $291 \cdot 1 \mathrm{bp}(0 \cdot 0 \mathrm{bp})$ in common.

All eight CDC II-h strains tested (NF 675, NF 690, NF 696, NF 802, NF 974, NF 1141, NF 1146 and NF 1335) had tRNA spacers with lengths of $57 \cdot 5(0 \cdot 2), 81 \cdot 1(0 \cdot 1), 90 \cdot 2(0 \cdot 1)$, $92 \cdot 3(0 \cdot 1), 110 \cdot 6(0 \cdot 1)$ and $218 \cdot 5 \mathrm{bp}(0 \cdot 1 \mathrm{bp})$ in common. As such, tDNA-PCR enabled differentiation between Wautersiella falsenii and the most closely related species.

Biochemical and morphological tests were performed as described previously (Laffineur et al., 2002) and by Schreckenberger et al. (2003). Assimilation-alkalinization of organic compounds was detected on Simmons' citrate agar base by replacing citrate with $0 \cdot 2 \%(\mathrm{w} / \mathrm{v})$ of various organic substrates, according to Martin et al. (1981). For casein hydrolysis, $1 \%(\mathrm{v} / \mathrm{v})$ of skimmed milk was added to nutrient agar plates. Enzymic reactions were carried out using diagnostic tablets from Rosco. Utilization of carbohydrates was performed using API $50 \mathrm{CH}$ strips (bioMérieux), which were read after 1, 2 and 3 days. The $\mathrm{KOH}$ test was used to detect flexirubin pigment (Bernardet et al., 2002).

Table 1. Clinical origins of the Wautersiella falsenii isolates

NF, Designation for non-fermenting strains from the collection of Georges Wauters, Université Catholique de Louvain, Brussels, Belgium.

\begin{tabular}{|llc|}
\hline Clinical origin & \multicolumn{1}{c|}{ Genomovar 1 } & Genomovar 2 \\
\hline Blood & NF 880 & NF 770, NF 1136, NF 1159, NF 1249 \\
Ear discharge & NF 835 & \\
Oral cavity & NF 976 & NF 622 \\
Pleural fluid & NF 777 & \\
Pus & NF 1242 & \\
Respiratory tract & NF 869, NF 1240 & \\
Surgical wound & NF 993 & NF 1080, NF 1084, NF 1138, NF 1140 \\
Vaginal swab & NF 1243 & NF 58, NF 203, NF 316 \\
Wound & NF 289, NF 987, NF 1182, NF 1241, NF 1244 \\
Unknown &
\end{tabular}




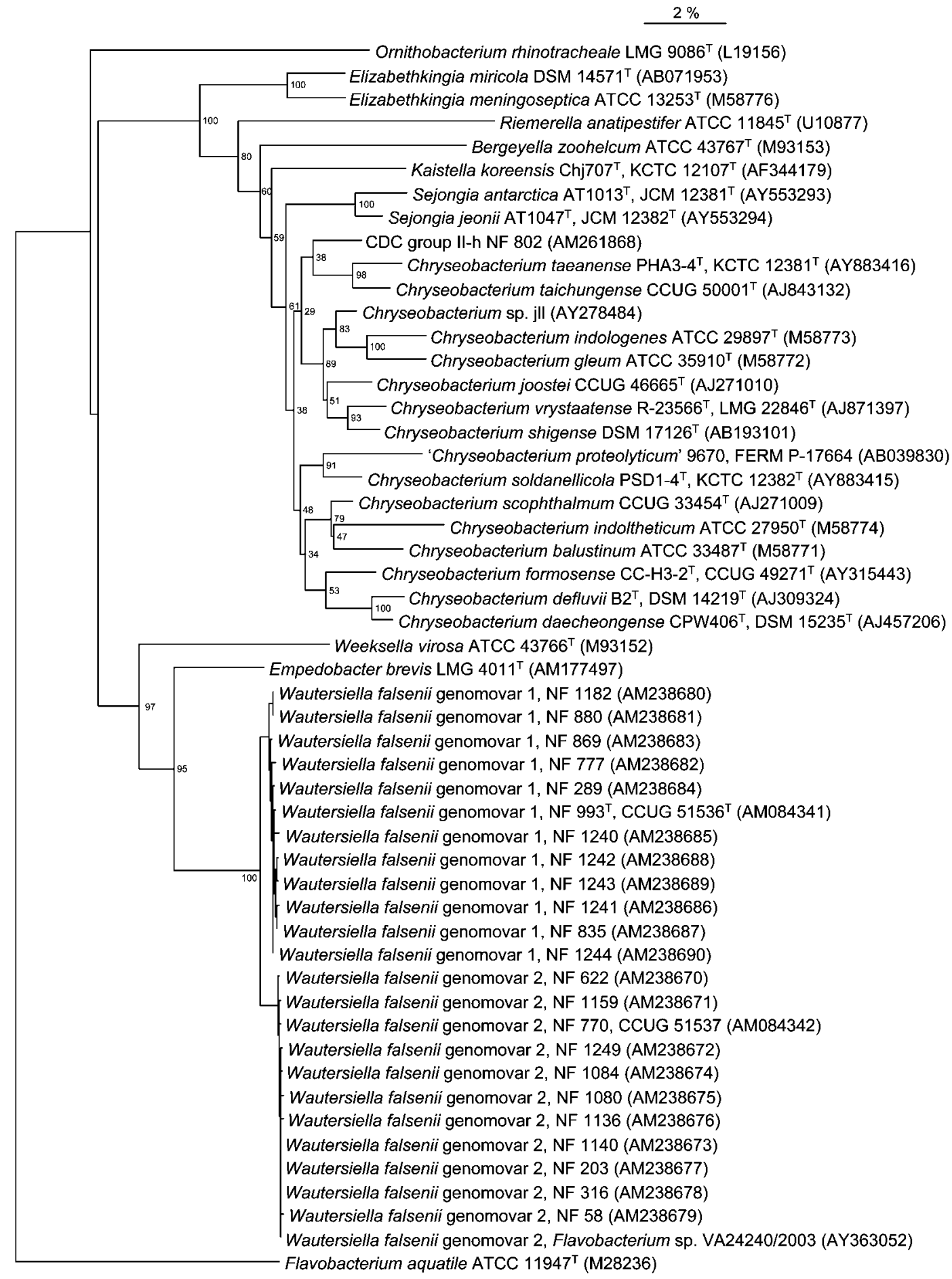

Fig. 1. Rooted tree based on $16 \mathrm{~S}$ rRNA gene sequences of strains of Wautersiella falsenii gen. nov., sp. nov. and related genera. Cluster analysis was performed using Genebase (Applied Maths) and was based on the neighbour-joining method, with the 16S rRNA gene sequence of Flavobacterium aquatile as an outgroup. Percentage bootstrap values $(n=100)$ are shown at branch points. Bar, $2 \%$ dissimilarity.

All isolates were Gram-negative, non-motile, non-fermenting rods and were oxidase- and catalase-positive. Some strains displayed yellow-pigmented colonies after prolonged incubation, but the pigment was not of the flexirubin type.
Acid was produced from glucose and maltose. Lysine and ornithine decarboxylases and arginine dihydrolase were negative. Indole was produced and urease was positive using Christensen's urea broth. Nitrate reduction was negative 

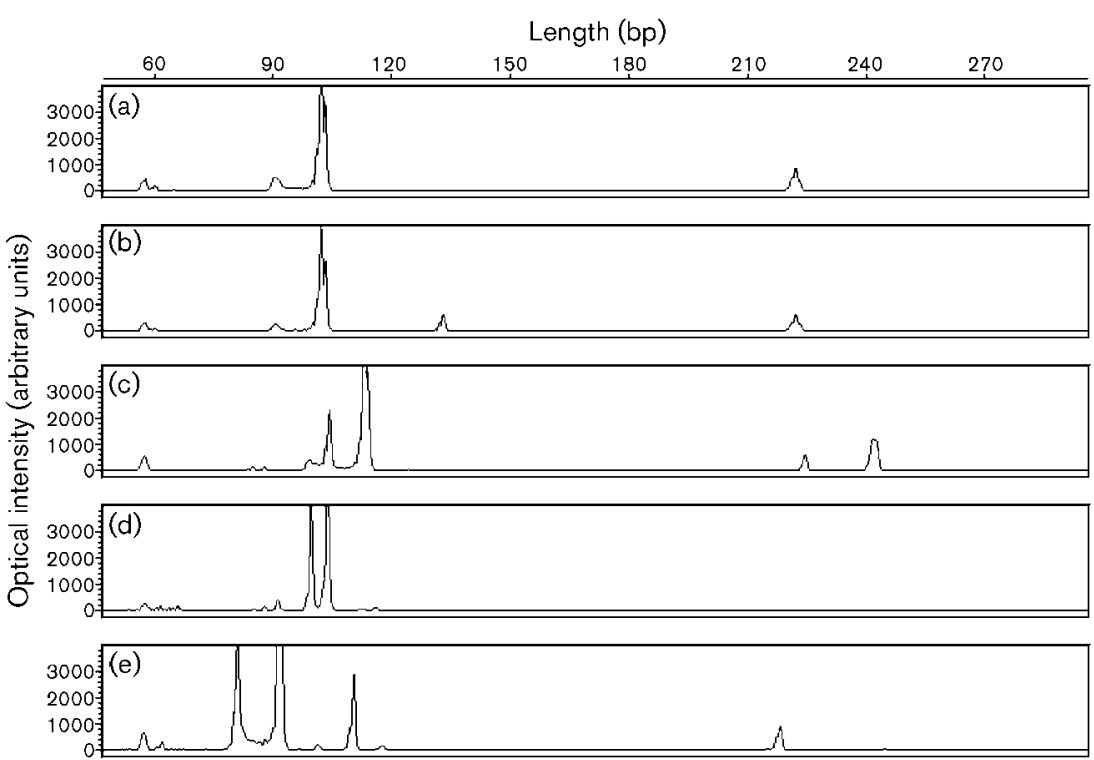

Fig. 2. tDNA-PCR fingerprints of representative strains of the two genomovars of Wautersiella falsenii gen. nov., sp. nov., Empedobacter brevis, Weeksella virosa and CDC group II-h. (a) Wautersiella falsenii genomovar 1, NF 998'; (b) Wautersiella falsenii genomovar 2, NF 1080; (c) Empedobacter brevis LMG 4011 ${ }^{\top}$; (d) Weeksella virosa NF 309; (e) CDC group II-h, NF 802. and nitrite reduction was mostly negative. Gelatinase production varied from weak to strong and was in general faster and stronger for genomovar 1 isolates. Casein hydrolysis was negative or very weak. Growth did not occur at $42{ }^{\circ} \mathrm{C}$. Assimilation and alkalinization of acetate, aspartate, L-alanine and L-serine were positive on Simmons' agar base, whereas citrate and most of the other organic salts were negative. Isolates were variable for galacturonate. Aesculin hydrolysis was variable. Alkaline phosphatase, trypsin, pyrrolidonyl aminopeptidase, $\alpha$-glucosidase and $N$ acetyl-glucosaminidase were positive, whereas $\alpha$-galactosidase, $\alpha$-mannosidase, $\alpha$-fucosidase and $\beta$-xylosidase were negative. $\beta$-galactosidase (ONPG) was variable. On API 50 $\mathrm{CH}$ strips, only maltose, glycerol and starch were assimilated within 3 days. Glucose was assimilated by some of the isolates. Table 2 summarizes some of the biochemical characteristics that differ between the two genomovars; aesculin, ONPG and galacturonate yielded characteristic reactions that separated the two genomovars, but exceptions occurred and isolate NF 1138, belonging to genomovar 2, even had the biochemical profile of genomovar 1 . Empedobacter brevis differed from all Wautersiella falsenii isolates in being urease-negative and having strong casein hydrolysis activity (Table 2). All CDC II-h isolates were urease-negative, in contrast to the Wautersiella falsenii isolates.

Fatty acid analysis was carried out as described previously (Kämpfer \& Kroppenstedt, 1996; Kämpfer et al., 2003). The most abundant fatty acid was $15: 0$ iso, followed by summed feature 4 ( $15: 0$ iso $2-\mathrm{OH}$ and/or $16: 1 \omega 7 c t), 17: 0$ iso $3-\mathrm{OH}$ and 15:0 iso $3-\mathrm{OH}$. The fatty acid profiles of strains of the two genomovars were different from those of Empedobacter brevis and Chryseobacterium species (Table 3 ).

Table 2. Differential biochemical characteristics for Wautersiella falsenii genomovars 1 and 2, Empedobacter brevis and Weeksella virosa

Results are given as the percentage of positive isolates. Strains used were: Wautersiella falsenii (as listed in Table 1); Empedobacter brevis LMG 4011 ${ }^{\mathrm{T}}$, NF 285 and NF 1052; and Weeksella virosa LMG 12995 ${ }^{\mathrm{T}}$, LMG 8349, NF 309, NF 637, NF 805, NF 947 and NF 1063.

\begin{tabular}{|c|c|c|c|c|}
\hline \multirow[t]{2}{*}{ Characteristic } & \multicolumn{2}{|c|}{ Wautersiella falsenii } & \multirow[t]{2}{*}{ Empedobacter brevis $(n=3)$} & \multirow[t]{2}{*}{ Weeksella virosa $(n=7)$} \\
\hline & Genomovar $1(n=14)$ & Genomovar $2(n=12)$ & & \\
\hline Aesculin hydrolysis $(4 \mathrm{~h})$ & 100 & 8 & 0 & 0 \\
\hline Galacturonate alkalinization & 93 & 8 & 0 & 0 \\
\hline Gelatin hydrolysis $(24 \mathrm{~h})$ & 100 & 8 (weak: 92) & 100 & 100 \\
\hline$\beta$-Galactosidase (ONPG) & 0 & 75 & 0 & 0 \\
\hline Casein hydrolysis (within $8 \mathrm{~h}$ ) & 0 & 0 & 100 & 0 \\
\hline Urease & 100 & 100 & 0 & 0 \\
\hline Colistin resistance & 100 & 100 & 100 & 0 \\
\hline Acid from glucose and maltose & 100 & 100 & 100 & 0 \\
\hline
\end{tabular}


Table 3. Long-chain fatty acid composition of Wautersiella falsenii gen. nov., sp. nov. and related bacteria

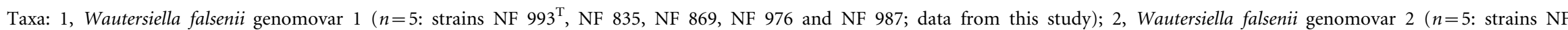

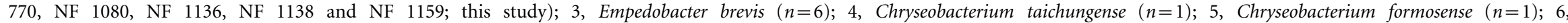

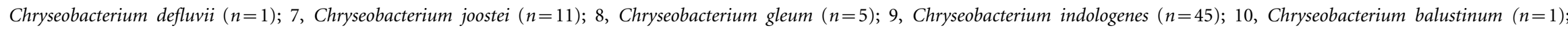

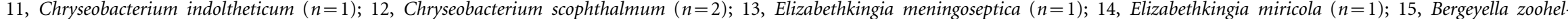

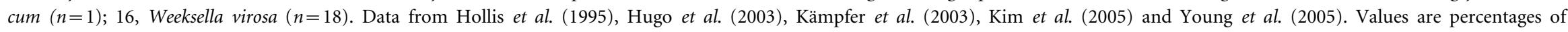
total fatty acids. Where applicable means \pm SD are given. tr, Trace (less than $1.0 \%$ ); ND, not detected.

\begin{tabular}{|c|c|c|c|c|c|c|c|c|c|c|c|c|c|c|c|c|}
\hline Fatty acid & 1 & 2 & 3 & 4 & 5 & 6 & 7 & 8 & 9 & 10 & 11 & 12 & 13 & 14 & 15 & 16 \\
\hline $\begin{array}{c}\text { Unknown } \\
11 \cdot 543^{\star}\end{array}$ & $1 \cdot 25 \pm 0 \cdot 15$ & $0 \cdot 88 \pm 0 \cdot 45$ & & & & & & & & & & & & & & \\
\hline $13: 0$ iso & $\operatorname{tr}$ & & $\operatorname{tr}$ & $\operatorname{tr}$ & $3 \cdot 6$ & $2 \cdot 8$ & $\operatorname{tr}$ & $\operatorname{tr}$ & $\operatorname{tr}$ & $\operatorname{tr}$ & $\mathrm{ND}$ & $\operatorname{tr}$ & $1 \cdot 3 \pm 0 \cdot 3$ & $2 \cdot 0 \pm 0 \cdot 5$ & $1 \cdot 5$ & 1 \\
\hline $\begin{array}{c}13: 1 \mathrm{AT} \\
12-13 \dagger\end{array}$ & $1 \cdot 16 \pm 0 \cdot 31$ & $1 \cdot 4 \pm 0 \cdot 43$ & & & & & & & & & & & & & & \\
\hline $14: 1 \omega 5 c$ & $\operatorname{tr}$ & $\operatorname{tr}$ & & & & & & & & & & & & & & \\
\hline $14: 0$ & $1 \cdot 38 \pm 0 \cdot 21$ & $1 \cdot 1 \pm 0 \cdot 1$ & & & & & & & & & & & & & & $\operatorname{tr}$ \\
\hline $14: 02-\mathrm{OH}$ & $\operatorname{tr}$ & $\operatorname{tr}$ & & & & & & & & & & & & & & \\
\hline $\begin{array}{l}\text { Unknown } \\
13 \cdot 566^{*}\end{array}$ & $4 \cdot 24 \pm 1 \cdot 4$ & $6 \cdot 55 \pm 2 \cdot 21$ & $1 \cdot 9 \pm 1 \cdot 4$ & $6 \cdot 7$ & $\operatorname{tr}$ & $\operatorname{tr}$ & $1 \cdot 1 \pm 0 \cdot 2$ & $1 \cdot 2 \pm 0 \cdot 4$ & $2 \cdot 1 \pm 0 \cdot 7$ & $1 \cdot 6$ & $1 \cdot 7$ & $2 \cdot 9 \pm 0 \cdot 2$ & $1 \cdot 9 \pm 0 \cdot 3$ & $1 \cdot 5 \pm 0 \cdot 2$ & $1 \cdot 8$ & 2 \\
\hline $\begin{array}{l}15: 0 \text { iso } \\
15: 0 \text { iso } 2-\mathrm{OH}\end{array}$ & $31 \cdot 62 \pm 0 \cdot 86$ & $25 \cdot 83 \pm 1 \cdot 8$ & $23 \cdot 6 \pm 2 \cdot 2$ & $35 \cdot 4$ & $52 \cdot 2$ & $58 \cdot 5$ & $34 \cdot 6 \pm 2 \cdot 0$ & $35 \cdot 4 \pm 2 \cdot 9$ & $34 \cdot 3 \pm 4 \cdot 9$ & $32 \cdot 3$ & $29 \cdot 4$ & $35 \cdot 0 \pm 0 \cdot 7$ & $43 \cdot 9 \pm 2 \cdot 0$ & $46 \cdot 4 \pm 2 \cdot 2$ & $47 \cdot 8$ & $\begin{array}{l}46 \\
10\end{array}$ \\
\hline $15: 0$ iso $3-\mathrm{OH}$ & $8 \cdot 2 \pm 2 \cdot 0$ & $5 \cdot 58 \pm 0 \cdot 58$ & $4 \cdot 8 \pm 0 \cdot 7$ & $4 \cdot 3$ & $1 \cdot 8$ & $2 \cdot 6$ & $2 \cdot 9 \pm 0 \cdot 3$ & $2 \cdot 5 \pm 0 \cdot 1$ & $2 \cdot 6 \pm 0 \cdot 2$ & $2 \cdot 7$ & $2 \cdot 3$ & $2 \cdot 7 \pm 0 \cdot 1$ & $2 \cdot 8 \pm 0 \cdot 3$ & $3 \cdot 0 \pm 0 \cdot 6$ & $4 \cdot 0$ & 5 \\
\hline $15: 0$ anteiso & & & $\operatorname{tr}$ & $0 \cdot 7$ & $2 \cdot 1$ & $3 \cdot 2$ & $\operatorname{tr}$ & $\operatorname{tr}$ & $\operatorname{tr}$ & $\operatorname{tr}$ & $5 \cdot 9$ & $\operatorname{tr}$ & $1 \cdot 1 \pm 0 \cdot 8$ & $1 \cdot 0 \pm 0 \cdot 6$ & ND & ND \\
\hline $15: 0$ & $\operatorname{tr}$ & $\operatorname{tr}$ & & & & & & & & & & & & & & ND \\
\hline $15: 1 \omega 6 c$ & $\operatorname{tr}$ & $\operatorname{tr}$ & & & & & & & & & & & & & & \\
\hline $\begin{array}{l}16: 0 \\
16: 0 \text { iso }\end{array}$ & $3 \cdot 2 \pm 1 \cdot 36$ & $4 \cdot 98 \pm 0 \cdot 73$ & $3 \cdot 8 \pm 0 \cdot 4$ & $1 \cdot 3$ & $1 \cdot 5$ & $1 \cdot 3$ & $\operatorname{tr}$ & $1 \cdot 3 \pm 0 \cdot 4$ & $\operatorname{tr}$ & $1 \cdot 6$ & $1 \cdot 0$ & $1 \cdot 2 \pm 0 \cdot 2$ & $\operatorname{tr}$ & $1 \cdot 2 \pm 0 \cdot 1$ & $\operatorname{tr}$ & $\begin{array}{l}4 \\
1\end{array}$ \\
\hline $16: 03-\mathrm{OH}$ & $4 \cdot 58 \pm 0 \cdot 95$ & $3 \cdot 05 \pm 0 \cdot 50$ & $3 \cdot 6 \pm 0 \cdot 7$ & $2 \cdot 6$ & $\operatorname{tr}$ & $\operatorname{tr}$ & $1 \cdot 2 \pm 0 \cdot 2$ & $1 \cdot 1 \pm 0 \cdot 1$ & $1 \cdot 0 \pm 0 \cdot 2$ & $1 \cdot 4$ & $\operatorname{tr}$ & $1 \cdot 0 \pm 0 \cdot 1$ & $2 \cdot 6 \pm 0 \cdot 4$ & $3 \cdot 0 \pm 0 \cdot 6$ & $\mathrm{ND}$ & 1 \\
\hline $\begin{array}{c}16: 0 \text { iso } \\
3-\mathrm{OH}\end{array}$ & $0 \cdot 96 \pm 0 \cdot 16$ & $1 \cdot 23 \pm 0 \cdot 38$ & $\operatorname{tr}$ & $1 \cdot 4$ & $1 \cdot 1$ & $\operatorname{tr}$ & ND & ND & ND & $\operatorname{tr}$ & $1 \cdot 3$ & ND & $\operatorname{tr}$ & $\operatorname{tr}$ & $\mathrm{ND}$ & ND \\
\hline $16: 1 \omega 5 c$ & $4 \cdot 74 \pm 1 \cdot 03$ & $5 \cdot 55 \pm 0 \cdot 77$ & & & & & & & & & & & & & & 1 \\
\hline $\begin{array}{c}\text { Unknown } \\
16 \cdot 580^{*}\end{array}$ & $1 \cdot 24 \pm 0 \cdot 24$ & $1 \cdot 5 \pm 0 \cdot 07$ & $1 \cdot 4 \pm 0 \cdot 1$ & $1 \cdot 7$ & $1 \cdot 0$ & ND & $1 \cdot 6 \pm 0 \cdot 1$ & $1 \cdot 7 \pm 0 \cdot 1$ & $1 \cdot 7 \pm 0 \cdot 2$ & $1 \cdot 3$ & $1 \cdot 3$ & $1 \cdot 5 \pm 0 \cdot 1$ & $1 \cdot 6 \pm 0 \cdot 1$ & $1 \cdot 3 \pm 0 \cdot 6$ & $1 \cdot 4$ & \\
\hline $17: 02-\mathrm{OH}$ & $\operatorname{tr}$ & $\operatorname{tr}$ & $\operatorname{tr}$ & $\mathrm{ND}$ & $\mathrm{ND}$ & ND & ND & ND & ND & $\operatorname{tr}$ & $3 \cdot 0$ & $\operatorname{tr}$ & $\mathrm{ND}$ & ND & $\mathrm{ND}$ & \\
\hline $17: 0$ iso & $1 \cdot 1 \pm 0 \cdot 45$ & $1 \cdot 23 \pm 0 \cdot 48$ & $\operatorname{tr}$ & $0 \cdot 8$ & $2 \cdot 3$ & $2 \cdot 0$ & $\operatorname{tr}$ & $1 \cdot 6 \pm 0 \cdot 6$ & $\operatorname{tr}$ & $1 \cdot 0$ & $\operatorname{tr}$ & $\operatorname{tr}$ & $\operatorname{tr}$ & $\operatorname{tr}$ & $\mathrm{ND}$ & 3 \\
\hline $\begin{array}{c}17: 0 \text { iso } \\
3-\mathrm{OH}\end{array}$ & $13 \cdot 32 \pm 1 \cdot 67$ & $13 \cdot 85 \pm 1 \cdot 86$ & $17 \cdot 1 \pm 2 \cdot 1$ & $22 \cdot 4$ & $10 \cdot 9$ & $14 \cdot 1$ & $20 \cdot 1 \pm 1 \cdot 2$ & $21 \cdot 8 \pm 0 \cdot 3$ & $19 \cdot 2 \pm 1 \cdot 8$ & $16 \cdot 8$ & $14 \cdot 0$ & $16 \cdot 3 \pm 0 \cdot 1$ & $14 \cdot 6 \pm 1 \cdot 0$ & $15 \cdot 3 \pm 0 \cdot 2$ & $13 \cdot 5$ & 7 \\
\hline $17: 1$ iso $\omega 8 c$ & & & & & & & & & & & & & & & & 5 \\
\hline $17: 1$ iso $\omega 9 c$ & $1 \cdot 22 \pm 0 \cdot 31$ & $2 \cdot 3 \pm 0 \cdot 47$ & $3 \cdot 9 \pm 0 \cdot 5$ & $8 \cdot 9$ & $4 \cdot 3$ & $4 \cdot 8$ & $22 \cdot 9 \pm 1 \cdot 9$ & $20 \cdot 2 \pm 3 \cdot 9$ & $24 \cdot 2 \pm 3 \cdot 1$ & $27 \cdot 1$ & $25 \cdot 6$ & $24 \cdot 8 \pm 0 \cdot 4$ & $7 \cdot 8 \pm 1 \cdot 3$ & $6 \cdot 6 \pm 0 \cdot 2$ & $17 \cdot 5$ & \\
\hline $17: 1$ iso $\omega 12 t$ & & & & & & & & & & & & & & & & 8 \\
\hline $18: 0$ & & & & & & & & & & & & & & & & 1 \\
\hline
\end{tabular}




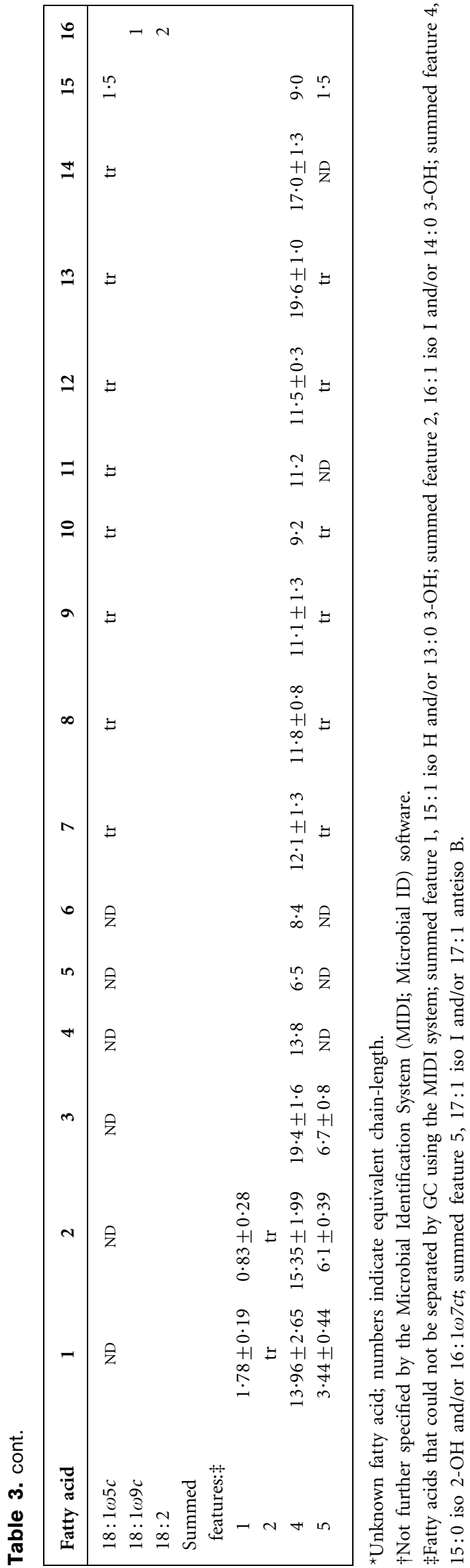

The DNA G $+\mathrm{C}$ contents, determined according to the method of Peña et al. (2005), of the type strain of genomovar 1 and the reference strain of genomovar 2 were $33 \cdot 8 \pm 0 \cdot 4$ and $34 \cdot 4 \pm 0 \cdot 2 \%$, respectively, in agreement with values obtained for the closely related genera Chryseobacterium and Empedobacter (Bernardet et al., 2002).

For DNA-DNA hybridization, a microplate method was used, modified after Lind \& Ursing (1986), and as described by Ziemke et al. (1998). Reciprocal DNA-DNA hybridizations, i.e. with one of the two strains labelled first and the other labelled subsequently, were carried out between the two reference strains of Wautersiella falsenii and Empedobacter brevis LMG $4011^{\mathrm{T}}$. Values obtained were $29 \cdot 4 \%$ (respectively $25.5 \%$ reciprocal) for Wautersiella falsenii genomovar 1 strain NF $993^{\mathrm{T}}$ versus Empedobacter brevis LMG $4011^{\mathrm{T}}$ and $33 \cdot 0 \%$ (respectively $35 \cdot 8 \%$ reciprocal) for Wautersiella falsenii genomovar 2 strain NF 770 versus Empedobacter brevis LMG $4011^{\mathrm{T}}$, indicating that the reference strains of the two genomovars do not belong to Empedobacter brevis.

DNA-DNA hybridization values of $104 \cdot 6 \%$ (respectively reciprocal $103 \cdot 0 \%$ ) were obtained for genomovar 1 strains $\mathrm{NF} 993^{\mathrm{T}}$ and NF $835,86.6 \%$ (respectively reciprocal $93.9 \%$ ) for strains NF $993^{\mathrm{T}}$ and NF 869 and $88.2 \%$ and $93.5 \%$ for genomovar 2 reference strain NF 770 with, respectively, isolates NF 1084 and NF 1138. A value of $63.6 \%$ was obtained for strain NF $993^{\mathrm{T}}$ (labelled) versus strain NF 770, indicating that the two strains represent separate genomovars and borderline the same species.

Although two separate groups are clearly present within the genus Wautersiella, at present it is not possible to describe them as separate species, because of the lack of a phenotypic characteristic that can unambiguously differentiate between the two groups. Therefore it was decided to describe the two groups as genomovars.

\section{Description of Wautersiella gen. nov.}

Wautersiella (Wau.ter'si.ella. N.L. fem. dim. n. Wautersiella named after Georges Wauters, a contemporary Belgian microbiologist, who first recognized this group of organisms as a separate entity and to honour him for his lifelong contribution to bacterial taxonomy).

Non-motile, Gram-negative rods, $2-3 \mu \mathrm{m}$ in length, growing aerobically at 20,30 and $37^{\circ} \mathrm{C}$ on standard media such as tryptic soy agar or blood agar. Colonies are approximately $2 \mathrm{~mm}$ in diameter after growth on blood agar for $48 \mathrm{~h}$ at $30{ }^{\circ} \mathrm{C}$. Main cellular fatty acids are 15:0 iso, $17: 0$ iso $3-\mathrm{OH}$, summed feature 4 and $15: 0$ iso $3-\mathrm{OH}$. The $\mathrm{G}+\mathrm{C}$ content of the DNA is $33 \cdot 8-34 \cdot 4 \mathrm{~mol} \%$. The type and only species is Wautersiella falsenii.

\section{Description of Wautersiella falsenii sp. nov.}

Wautersiella falsenii (fal.sen'i.i. N.L. gen. n. falsenii of Falsen, to honour the contemporary Norwegian microbiologist, 
Enevold Falsen, for his lifelong interest in bacterial taxonomy and for his systematic characterization of bacteria at the CCUG, Göteborg, Sweden).

Oxidative acidification of glucose and maltose. Positive for urease and for indole production. Nitrates are not reduced, but nitrite reduction is variable. Lysine and ornithine decarboxylases and arginine dihydrolase are not present. Citrate is negative. Alkaline phosphatase, trypsin (benzylarginine arylamidase) and pyrrolidonyl aminopeptidase are positive. Gelatin hydrolysis is positive or weakly and delayed positive. Casein hydrolysis is negative or weakly and delayed positive. Comprises two genomovars that differ in $16 \mathrm{~S}$ rRNA gene sequence and in tDNA-PCR pattern. All genomovar 1 isolates $(n=14)$ rapidly hydrolyse gelatin and aesculin, are $\beta$-galactosidase (ONPG)-negative and all but one alkalinize galacturonate. All genomovar 2 isolates $(n=12)$ but one are aesculin- and galacturonate-negative. Most isolates are ONPG-positive and slightly gelatinpositive. Fatty acids are as described for the genus, with only minor differences between the two genomovars.

The type strain of the species and reference strain for genomovar 1 is NF $993^{\mathrm{T}}\left(=\mathrm{CCUG} 51536^{\mathrm{T}}=\mathrm{CIP} 108861^{\mathrm{T}}\right)$, which was isolated from a surgical wound. The reference strain for genomovar 2, NF 770 (=CCUG $51537=$ CIP 108860), was isolated from blood.

\section{Acknowledgements}

Professor Dr Rosselló-Mora [Institut Mediterrani d'Estudis Avançats (IMEDEA, CSIC-UIB), Esporles, Illes Balears, Spain] is acknowledged for carrying out the DNA $\mathrm{G}+\mathrm{C}$ content determination. The authors thank Leen Van Simaey and Catharine De Ganck for excellent technical assistance.

\section{References}

Baele, M., Baele, P., Vaneechoutte, M., Storms, V., Butaye, P., Devriese, L. A., Verschraegen, G., Gillis, M. \& Haesebrouck, F. (2000). Application of tRNA intergenic spacer PCR for identification of Enterococcus species. J Clin Microbiol 38, 4201-4207.

Bernardet, J.-F., Nakagawa, Y. \& Holmes, B. (2002). Proposed minimal standards for describing new taxa of the family Flavobacteriaceae and emended description of the family. Int J Syst Evol Microbiol 52, 1049-1070.

Hollis, D. G., Daneshvar, M. I., Moss, C. W. \& Baker, C. N. (1995). Phenotypic characteristics, fatty acid composition, and isoprenoid quinine content of CDC group IIg bacteria. J Clin Microbiol 33, $762-764$.
Hugo, C. J., Segers, P., Hoste, B., Vancanneyt, M. \& Kersters, K. (2003). Chryseobacterium joostei sp. nov., isolated from the dairy environment. Int J Syst Evol Microbiol 53, 771-777.

Kämpfer, P. \& Kroppenstedt, R. M. (1996). Numerical analysis of fatty acid patterns of coryneform bacteria and related taxa. Can J Microbiol 42, 989-1005.

Kämpfer, P., Dreyer, U., Neef, A., Dott, W. \& Busse, H.-J. (2003). Chryseobacterium defluvii sp. nov., isolated from wastewater. Int J Syst Evol Microbiol 53, 93-97.

Kim, K. K., Kim, M. K., Lim, J. H., Park, H. Y. \& Lee, S.-T. (2005). Transfer of Chryseobacterium meningosepticum and Chryseobacterium miricola to Elizabethkingia gen. nov. as Elizabethkingia meningoseptica comb. nov. and Elizabethkingia miricola comb. nov. Int J Syst Evol Microbiol 55, 1287-1293.

Laffineur, K., Janssens, M., Charlier, J., Avesani, V., Wauters, G. \& Delmée, M. (2002). Biochemical and susceptibility tests useful for identification of nonfermenting gram-negative rods. J Clin Microbiol 40, 1085-1087.

Lind, E. \& Ursing, J. (1986). Clinical strains of Enterobacter agglomerans (synonyms: Erwinia herbicola, Erwinia milletiae) identified by DNA-DNA-hybridization. Acta Pathol Microbiol Immunol Scand $[B]$ 94, 205-213.

Martin, R., Riley, P. S., Hollis, D. G., Weaver, R. E. \& Krichevsky, M. I. (1981). Characterization of some groups of gram-negative nonfermentative bacteria by the carbon source alkalinization technique. J Clin Microbiol 14, 39-47.

Nemec, A., De Baere, T., Tjernberg, I., Vaneechoutte, M., van der Reijden, T. J. K. \& Dijkshoorn, L. (2001). Acinetobacter ursingii sp. nov. and Acinetobacter schindleri sp. nov., isolated from human clinical specimens. Int J Syst Evol Microbiol 51, 1891-1899.

Peña, A., Valens, M., Santos, F., Buczolits, S., Antón, J., Kämpfer, P., Busse, H.-J., Amann, R. \& Rosselló-Mora, R. (2005). Intraspecific comparative analysis of the species Salinibacter ruber. Extremophiles 9, 151-161.

Schreckenberger, P. C., Daneshvar, M. I., Weyant, S. R. \& Hollis, D. G. (2003). Acinetobacter, Achromobacter, Chryseobacterium, Moraxella, and other nonfermentative gram-negative rods. In Manual of Clinical Microbiology, 8th edn, pp. 749-779. Edited by P. R. Murray, E. J. Baron, J. H. Jorgensen, M. A. Pfaller \& R. H. Yolken. Washington, DC: American Society for Microbiology.

Vandamme, P., Bernardet, J.-F., Segers, P., Kersters, K. \& Holmes, B. (1994). New perspectives in the classification of the flavobacteria: description of Chryseobacterium gen. nov., Bergeyella gen. nov., and Empedobacter nom. rev. Int J Syst Bacteriol 44, 827-831.

Wauters, G., Charlier, J., Janssens, M. \& Delmée, M. (2001). Brevibacterium paucivorans sp. nov., from human clinical specimens. Int J Syst Evol Microbiol 51, 1703-1707.

Young, C.-C., Kämpfer, P., Shen, F.-T., Lai, W.-A. \& Arun, A. B. (2005). Chryseobacterium formosense sp. nov., isolated from the rhizosphere of Lactuca sativa L. (garden lettuce). Int J Syst Evol Microbiol 55, 423-426.

Ziemke, F., Höfle, M. G., Lalucat, J. \& Rosselló-Mora, R. (1998). Reclassification of Shewanella putrefaciens Owen's genomic group II as Shewanella baltica sp. nov. Int J Syst Bacteriol 48, 179-186. 